\title{
Quality of penicillin allergy management in the intensive care unit and internal medicine ward
}

\author{
Philippe Bégin ${ }^{1,2^{*}}$, Matthieu Picard ${ }^{1,2^{*}}$, Hugues Bouchard ${ }^{1}$, Jonathan Cloutier ${ }^{1}$, Émilie Daoust ${ }^{1}$, \\ Louis Paradis ${ }^{2}$, Brian Laufer ${ }^{1}$ \\ From Canadian Society of Allergy and Clinical Immunology Annual Scientific Meeting 2010 \\ Victoria, Canada. 3-6 November 2010
}

\section{Background}

Penicillin allergy is reported by $10 \%$ of the population [1]. The associated morbidity is substantial given its medical and economic implications [2-4]. The aim of this study was to assess the quality of care with regards to the management of penicillin allergy in a university affiliated general hospital with no allergy service.

\section{Material and methods}

All admissions from December $1^{\text {st }} 2008$ to December $1^{\text {st }}$ 2009 were hand reviewed for a notion of penicillin allergy. Files were then assessed for (1) quality of allergic history to penicillin, (2) referral to an allergy clinic upon discharge, (3) indications for such a referral, (4) indication for a beta-lactam, and in the latter case, (5) management of antibiotic therapy.

\section{Results}

Of the 1738 files reviewed, 172 contained a notion of alleged penicillin allergy. History of the reaction to penicillin was poorly detailed even when patients required beta-lactam therapy (table 1). In the 87 patients who did require a beta-lactam, half received it without any skin testing, challenge or desensitization. No adverse reaction occurred. The main antibiotics used in the remaining patients were fluoroquinolones and vancomycin. Decision-making concerning the choice of antibiotic was documented in only $18 \%$. Upon discharge, only two patients were referred to an allergy clinic for elective penicillin skin testing, even though referral was strongly indicated in 97 patients (table 2).

\footnotetext{
* Correspondence: beginphil@gmail.com

'Department of medicine, Hôpital Maisonneuve-Rosemont, Université de Montréal, Montreal, Canada, H1T 2M4

Full list of author information is available at the end of the article
}

Table 1 Details included in allergy history

\begin{tabular}{lcc}
\hline & $\begin{array}{c}\text { All patients } \\
(\mathbf{n = 1 7 2 )}\end{array}$ & $\begin{array}{c}\text { Patients with indication for } \\
\text { beta-lactam }(\mathbf{n = 8 7})\end{array}$ \\
\hline $\begin{array}{l}\text { Allergy to penicillin noted } \\
\text { in admission note }\end{array}$ & $139(81 \%)$ & $69(79 \%)$ \\
Allergy tag on file & $119(69 \%)$ & $66(76 \%)$ \\
Molecule specified & $31(18 \%)$ & $23(26 \%)$ \\
Allergic reaction described & $52(30 \%)$ & $27(31 \%)$ \\
Delay since reaction noted & $7(4 \%)$ & $5(6 \%)$ \\
Treatment of allergic & 0 & 0 \\
reaction noted & & \\
\hline
\end{tabular}

\section{Conclusion}

Penicillin allergy is a frequent problem in hospital practice. Its management is not optimal in most cases. This study stresses the importance of continuous medical education on this subject and the importance of a readily available inpatient allergy service to support hospital practitioners.

Table 2 Strong arguments for allergy referral.

\begin{tabular}{lc}
\hline Argument & Number of patient $(\mathbf{n = 1 7 2})$ \\
\hline Allergy to a non beta-lactam antibiotic & $37(22 \%)$ \\
Immunosuppressive treatment & $15(9 \%)$ \\
Chronic disease (COPD, CKD on dialysis, & $85(49 \%)$ \\
complicated diabetes) & $72(42 \%)$ \\
Admitted for acute infection & $49(28 \%)$ \\
Planned surgery & $128(74 \%)$ \\
Any & $97(56 \%)$ \\
\hline
\end{tabular}




\section{Author details}

'Department of medicine, Hôpital Maisonneuve-Rosemont, Université de Montréal, Montreal, Canada, H1T 2M4. ${ }^{2}$ Department of medicine, Centre Hospitalier de I'Université de Montréal, Montreal, Canada, H2L 4M1.

Published: 4 November 2010

\section{References}

1. Solensky R: Hypersensitivity reactions to beta-lactam antibiotics. Clin Rev Allergy Immunol 2003, 24:201-20.

2. Lee $\mathrm{CE}$, et al: The incidence of antimicrobial allergies in hospitalized patients: implications regarding prescribing patterns and emerging bacterial resistance. Arch Intern Med 2000, 160:2819-22.

3. MacLaughlin EJ, Saseen JJ, Malone DC: Costs of beta-lactam allergies: selection and costs of antibiotics for patients with a reported betalactam allergy. Arch Fam Med 2000, 9:722-6.

4. Martinez LA: Role of environmental contamination as a risk factor for acquisition of vancomycin-resistant enterococci in patients treated in a medical intensive care unit. Arch Intern Med 2003, 163:1905-12.

doi:10.1186/1710-1492-6-S2-P1

Cite this article as: Bégin et al:: Quality of penicillin allergy management in the intensive care unit and internal medicine ward. Allergy, Asthma \& Clinical Immunology 2010 6(Suppl 2):P1.

\section{Submit your next manuscript to BioMed Central and take full advantage of:}

- Convenient online submission

- Thorough peer review

- No space constraints or color figure charges

- Immediate publication on acceptance

- Inclusion in PubMed, CAS, Scopus and Google Scholar

- Research which is freely available for redistribution

Submit your manuscript at www.biomedcentral.com/submit 